\title{
П.Г. Костюк
}

\section{Іони кальцію в клітинному ядрі}

Структура ядерної оболонки. Клітинні ядра мають складну за структурою оболонку, що відгороджує генетичний апарат від решти цитоплазми. Вона складається 3 двох мембран - зовнішньої та внутрішньої - між якими знаходиться порожнина - перинуклеарний простір. Важливо, що останній сполучений з люменом ендоплазматичного ретикулума (EP) у зв'язку 3 тим, що мембрана ЕР морфологічно сполучена 3 зовнішньою мембраною ядра; тому перинуклеарний простір можна розглянути як специфічну частину ЕP.

Тому значний інтерес має 3'ясування можливості наявності в ядрі власного кальцієвого депо, яке могло б функціонувати як посередник у передачі цитозольних кальцієвих сигналів у нуклеоплазму. Дійсно, за допомогою конфокальної мікроскопії була підтверджена наявність таких депо [5]. Вони утворюються між внутрішньою ядерною мембраною та прилеглою мембраною ЕР і можуть ефективно накопичувати $\mathrm{Ca}^{2+}$ за рахунок активності відповідної SERCAпомпи.

Відповідно повинні існувати молекулярні механізми, що передають сигнали в нуклеоплазму через внутрішню мембрану ядерної оболонки. Технічний інтерес має створення можливостей визначення наявності іонних каналів і рецепторів саме на цій мембрані. Це стало можливим завдяки розробленню техніки отримання ізольованих клітинних ядер 3 наступним усуненням зовнішньої ядерної мембрани через утримання їх в 1\%-му розчині цитрату натрію 3 додаванням 5 ммоль/л діетилтритолу. Така процедура призводить до усунення зовнішньої (C) П.Г. Костюк ядерної оболонки без пошкодження внутрішньої [7]. Після цього можлива реєстрація поодиноких іонних каналів методом patch-clamp ("nucleus attached patch-clamp").

Іонні канали ядерної оболонки. Найбільш помітними каналами ядерної оболонки є «канали великої провідності», які реєструються як у зовнішній, так і внутрішній мембранах. Їх провідність в мембранах ядер нейронів Пуркіньє мозочка практично ідентична $(198 \pm 27$ та 199 пк См \pm 17 пк См). Вони $є$ мало селективними для моновалентних катіонів та практично непроникними для двовалентних [1]. Аналогічні канали були також зареєстровані в нейронах гіпокампа. Їх активність залежала від потенціалу, який підтримувався на мембрані. В зовнішній мембрані вони були практично відкритими при негативних потенціалах, а при позитивних їх активність різко зменшувалась. I навпаки, на внутрішній мембрані потенціалзалежність відкритого стану була протилежною. На рис. 1 представлені записи активності таких каналів та їх вольт-амперні характеристики, а на рис. 2 - залежність відкритого стану від потенціалу мембрани (чорні кола позначають активність каналів зовнішньої, а білі кола - активність каналів внутрішньої мембрани).

Наявність зазначених каналів великої провідності характерна і для ядерних оболонок інших типів центральних нейронів. Очевидно, що такі канали забезпечують прямий зв'язок між нуклеоплазмою або цитоплазмою та перинуклеарним простором і забезпечують транспорт одновалентних катіонів між цими структурами. Тобто 

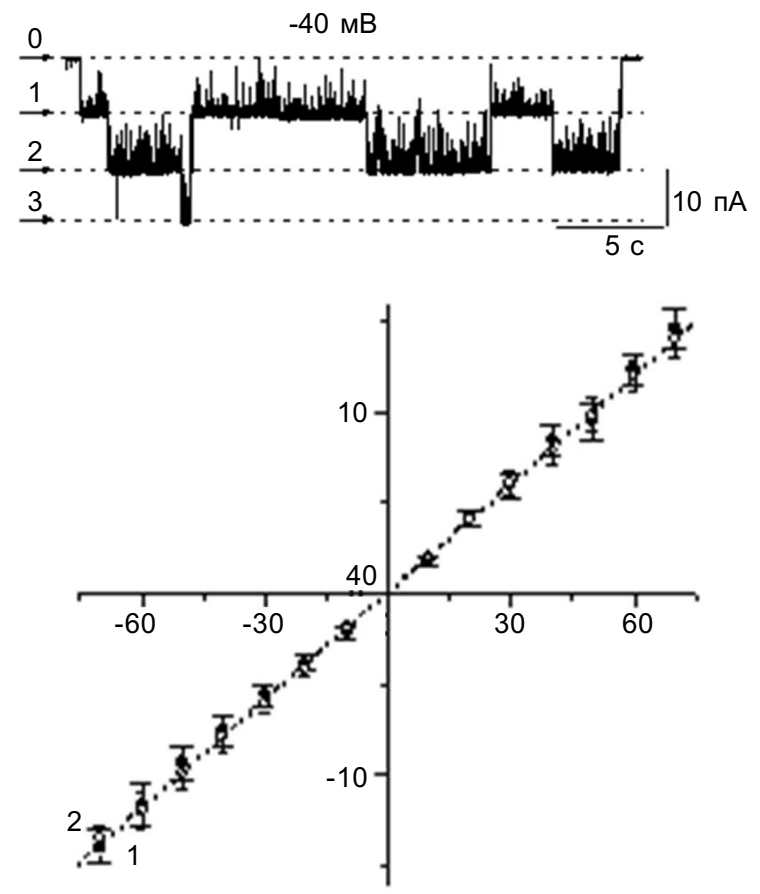

Рис. 1. Характеристики катіонних каналів великої провідності мембран ядерної оболонки нейронів Пуркіньє мозочка. Записи активності каналів (цифри зліва вказують на кількість відкритих каналів) та їх вольт-амперні характеристики для зовнішньої (1) та внутрішньої (2) мембрани в симетричному розчині 150 ммоль/л КСI

вони відповідають характеристикам, що властиві ядерним порам i, можливо, формують такі пори.

Актуальним є питання про те, чи можуть і яким механізмом можуть передаватися в клітинне ядро ті розглянуті вище внутрішньоклітинні сигнали, що виникають при життєдіяльності клітини. В цьому відношенні дуже важливим фактом є зазначена вище наявність в ядерній оболонці кальцієвого депо, яке споріднене з відповідним депо ЕР і створює можливість генерації ним кальцієвих сигналів у нуклеоплазму.

У цьому відношенні істотним є відкриття в ядерній мембрані $\mathrm{IP}_{3}$-рецепторних структур; ріанодинових рецепторів у ній не було виявлено [4]. При цьому дуже важливою виявилась експресія $\mathrm{IP}_{3}$-активованих кальцієвих каналів саме на внутрішній мембрані ядерної оболонки; відповідно при

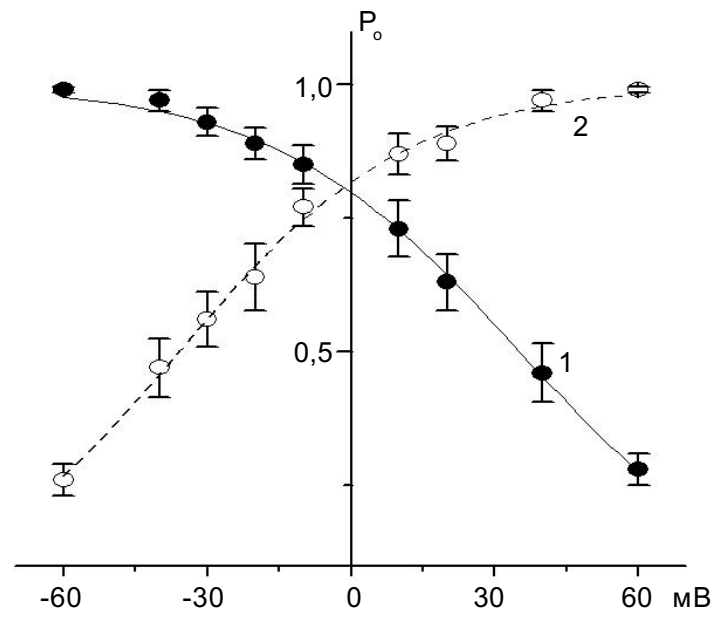

Рис. 2. Залежності відкритого стану катіонних каналів зовнішніх (1) та внутрішніх (2) ядерних мембран від трансмембранного потенціалу

їх активації буде виникати відтік $\mathrm{Ca}^{2+}$ безпосередньо в нуклеоплазму. Така активація можлива під впливом як $\mathrm{IP}_{3}$, так $\mathrm{i} \mathrm{Ca}^{2+}$.

Запропонована певна модель термінації відповідних кальцієвих каналів. Вивільнення $\mathrm{Ca}^{2+} 3$ перинуклеарного депо спряжене 3 перенесенням великого електричного заряду і буде призводити до появи негативного потенціалу в перинуклеарному просторі. При цьому активація катіонних каналів великої провідності буде зменшуватися. Можливо, що вони необхідні для тривалої регуляції активності $\mathrm{IP}_{3}$-рецепторів. При досягненні значних негативних значень цього потенціалу може наступити певне блокування $\mathrm{IP}_{3}$-рецепторів і припинення виділення $\mathrm{Ca}^{2+} 3$ депо в нуклеоплазму [4].

На рис. 3 представлена залежність вірогідності відкритого стану $\mathrm{IP}_{3}$-каналів ядерної оболонки нейронів Пуркіньє та пірамідальних нейронів від мембранного потенціалу.

Цікаво, що кальцієві сигнали в нуклеоплазмі можуть виникати з більш швидкою кінетикою, ніж аналогічні сигнали в цитоплазмі. Причиною цього є дуже тісні просторові зв'язки між перинуклеарним простором та нуклеоплазмою. Певно це має істотне значення для своєчасної та ефективної активації експресій генів та 
інших ядерних процесів. Особливе значення такі характеристики відповідних процесів мають в ембріональних клітинах, коли відбувається процеси їх диференціювання.

Функиї внутрішньоядерної сигналізації. Функціональна роль сигналів, що передаються в нуклеоплазму, складна і не повністю з'ясована. Вона проявляється вже на самих ранніх стадіях транскрипції генів родини C-fos i C-jun [8], залежність транскрипції C-fos-генів від вмісту $\mathrm{Ca}^{2+}$ в ядрі має дзвоноподібну характеристику з максимум близько 250 нмоль/л [10]. Навіть коротке (приблизно хвилина) підвищення цього рівня було достатнім для максимального впливу на швидкість транскрипції в гліальних і лейкемічних клітинах.

Цікаво, що ефективність таких змін у транскрипції залежала також від того, яким шляхом $\mathrm{Ca}^{2+}$ надходили в клітину з позаклітинного середовища. Так, у нейронах гіпокампа їх деполяризація гіперкалієвим розчином значно ефективніше стимулювала таку транскрипцію підвищенням $\left[\mathrm{Ca}^{2+}\right]_{\mathrm{i}}$ активацією NMDA-рецепторів [2]. Очевидно, просторові та часові характеристики кальцієвої хвилі істотні для визначення ефективності й очевидності внутрішньоядерної сигналізації.

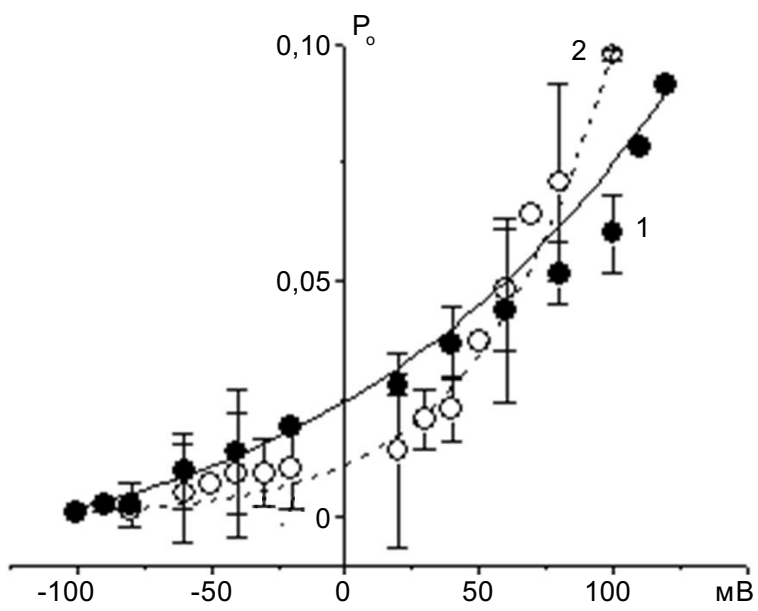

Рис. 3. Залежність сил вірогідності відкритого стану $\mathrm{IP}_{3}$-каналів внутрішньої ядерної мембрани нейронів Пуркіньє (1) та пірамідальних нейронів (2) від мембранного потенціалу
У нервових клітинах також продемонстрована залежність їх диференціації від надходження кальцієвих сигналів у нуклеоплазму, залежної від генетичної транскрипції. Так, у нейронах задньокорінцевих гангліїв відмічено зв'язок між ростом i розгалуженням їх нейритів і величиною внутрішньоядерних $\mathrm{Ca}^{2+}$-транзієнтів [3]. Такі сигнали значної амплітуди були зареєстровані саме в ембріональних нейронах цього типу; в постнатальних клітинах їх амплітуда істотно зменшувалася [9].

3 іншого боку, пригнічення можливості такої сигналізації спричиняє протилежні ефекти. Як пригнічення витоку іонів кальцію, так спустошення відповідних депо призводить до пригнічення клітинної диференціації в період максимального іiі розвитку, спричиненого відповідними процесами генетичної транскрипції [6]. Під час визрівання клітин послаблюється виникнення осциляцій; відповідно припиняється можливість їх реплікації та диференціації.

Разом $з$ тим питання про роль внутрішньоядерної кальцієвої сигналізації залишається певною мірою дискусійним, оскільки в багатьох дослідженнях не вдалося зареєструвати наявність істотної різниці у вмісті вільних іонів кальцію між цитоплазмою та нуклеоплазмою, яке могло б сприяти такій сигналізації. Ймовірно, що іони кальцію вільно проходять через внутрішньоядерну мембрану, що не підтримує можливості створення градієнта їх концентрації на цій мембрані, яка сприяла б виникненню відповідних сигналів.

\section{СПИСОК ЛІТЕРАТУРИ}

1. Федоренко О.А., Дужий Д.С., Марченко С.М. Катіонні канали великої провідності в ядерній оболонці нейронів Пуркіньє мозочка щурів // Нейрофізіологія/Neurophysiology. - 2007. - 39, №3. C. 13-18.

2. Bading H., Ginty D.D., Greenberg M.E. Regulation of gene expression in hippocampal neurons by distinct calcium signaling pathways // Science. -1993 . - 260. P. 181-186. 
3. Birch B.D., Eng D.L., Kocsis J.D. Intranuclear $\mathrm{Ca}^{2+}$ transients during neurite regeneration of an adult mammalian neuron // Proc. Nat. Acad. Sci. USA. 1993. - 89. - P. 7978-7982.

4. Fedorenko O.A., Duzhyy D.?.E?, Marchenko S.?M. $\mathrm{Ca}^{2+}$ channels in the nuclear membrane of hippocampal pyramidal neurons // Acta Physiol. -2006. - P. 183-186.

5. Gerasimenko O.V., Gerasimenko J.V., Tepikin A.V., Petersen O.H. ATP-dependent accumulation and inositol trisphosphate- or cyclic ADP-ribose-mediated release of $\mathrm{Ca}^{2+}$ from the nuclear envelope // Cell. 1995. - 80. - P. 439-444.

6. Holliday J., Adams R.J., Sejnowski T.J., Spitzer N.C. Calcium-induced release of calcium regulates differentiation of cultured spinal neurons // Neuron. - 1991. 7. -P. 787-796.

7. Humbert J.P., Matter N., Artault J.C., Koppler P.,

Ін-т фізіологї ім. О.О. Богомольия НАН України, Kü̈в
Malviya A.N. Inositol 1,4,5-trisphosphate receptor is located to the inner nuclear membrane vindicating regulation of nuclear calcium signaling by inositol 1,4,5trisphosphate. Discrete distribution of inositol phosphate receptors to inner and outer nuclear membranes // J. Biol. Chem. - 1996. - 271. - P. 478-485.

8. Roche E., Prentki M. Calcium regulation of immediateearly response genes // Cell. Calcium. - 1994. - 16. P. 331-338.

9. Utzschneider D.A., Rand M.N., Waxman S.G., Kocsis J.D. Nuclear and cytoplasmic $\mathrm{Ca}^{2+}$ signals in developing rat dorsal root ganglion neurons studied in excised tissue // Brain. Res. - 1994. - 635. - P. 231-237.

10. Werlen G., Belin D., Conne B., Roche E., Lew D.P., Prentki M. Intracellular $\mathrm{Ca}^{2+}$ and the regulation of early response gene expression in HL-60 myeloid leukemia cells // J. Biol. Chem. - 1993. - 268. - P. 16596-16601. 